\title{
TPM3/NTRK1 Fusion Protein
}

National Cancer Institute

\section{Source}

National Cancer Institute. TPM3/NT RK1 Fusion Protein. NCI Thesaurus. Code C18548.

A fusion protein (641 aa, 72 kDa) encoded by the TPM3/NT RK1 fusion gene. This protein is comprised of most of the tropomyosin alpha-3 chain protein fused to the Cterminus of the high affinity nerve growth factor receptor protein, including an intact tyrosine kinase domain. 